\title{
Precipitation conditions at the mountain study site of Bílý Kříž (the Beskids Mts.) during the past 20 years
}

\author{
${ }^{*}$ Irena Marková ${ }^{1}$, Dalibor Janouš ${ }^{1,2}$, Filip Holata ${ }^{1,2}$ \\ ${ }^{1}$ Centre MendelGlobe - Global climate change and managed ecosystems, Faculty of Forestry and Wood Technology, \\ Mendel University in Brno, Zemédèlská 3, Brno CZ-613 00, Czech Republic, markova@mendelu.cz \\ ${ }^{2}$ Global Change Research Institute - Czech Globe, Czech Academy of Sciences, v. v. i., Bëlidla 4a, Brno CZ-603 00, \\ Czech Republic
}

Abstract: Marková I., Janouš D., Holata F. 2017: Precipitation conditions at the mountain study site of Bílý Kř́íz (the Beskids Mts.) during the past 20 years. - Beskydy, 10 (1, 2): 9-16

\begin{abstract}
Expected global climate change can cause changes in several hydrological cycle processes, such as the intensity and frequency of precipitation, river flows, evapotranspiration rates, soil moisture, and groundwater recharge. Precipitation conditions have been observed at the mountain study site of Bílý Kř́íz (the Beskids Mts., Czech Republic) since 1989. This paper presents the analysis of long-term (1997-2016) precipitation conditions at this study site. Comparison of selected long-term mean precipitation characteristics with mean precipitation characteristics for the 1997-2016 period reported differences in only some parameters. The number of days without precipitation was slightly increasing. No statistically significant trend was found for the number of days with heavy rain. The study site was changed from being a per-humid to humid type as indicated by Lang'rain factor. More dry periods were determined at the past decade according to the standardized precipitation index.
\end{abstract}

Keywords: annual precipitation sum, precipitation intensity, drought period, Lang's rain factor, standardized precipitation index

\section{Introduction}

Expected global climate change can cause changes in several hydrological cycle processes, such as the intensity and frequency of precipitation, river flows, evapotranspiration rates, soil moisture and groundwater recharge (Michaelides et al. 2009, Vergni and Todisco 2011, Fiener et al. 2013, Peng et al. 2013). The amount, distribution, and intensity of the precipitation and resulting water availability can significant impacts on plant production, on the development and subsistence of all terrestrial ecosystems and human population (Poulter et al. 2013, Henttonen et al. 2014, Pessacg et al. 2015, Gu et al. 2016, Wai et al. 2017).

Trends in precipitation differed with latitudes: there was a $1 \%$ increase per decade during the $20^{\text {th }}$ century over the high and middle latitudes of the Northern hemisphere, a decrease over the sub-tropical area $\left(30^{\circ}\right.$ to $\left.10^{\circ} \mathrm{N}\right)$, a slight increase over the tropics, and no change at all in the southern hemisphere (Ventura et al. 2002). Mean annual precipitation is increasing with altitude (Jódar et al. 2016). The distribution of precipitation can influence water availability at some sites (Michaelides et al. 2009). The distribution and intensity of precipitation occur are most likely to happened due to the expected global climate change (Allen and Ingram 2002, Wilson and Toumi 2005, Haerter et al. 2010), Extreme precipitation has been studied very often in recent years (Begueria and VincenteSerrano 2006, Szolgay et al. 2009) because 
extreme precipitation events can cause flash floods (Rotunno and Houze 2007, Trapero et al. 2013) and soil erosion (D'Asaro et al. 2007, Meusburger et al. 2012, Fiener et al. 2013). On the other hand, climate change can increase climate variability and bring higher frequency of drought periods (Jongen et al. 2011, Ford and Labosier 2017).

This paper presents an analysis of long-term (1997-2016) precipitation conditions at the mountain study site of Bílý Kříž (the Beskids Mts., the Czech Republic).

\section{Material and Methods}

Precipitation characteristics have been observed at the mountain study site of Bílý Kříž (the Beskids Mts., Czech Republic) since 1989. Coordinates of the study site are 49 $30^{\prime} \mathrm{N}$ and $18^{\circ} 32^{\prime} \mathrm{E}$ and altitude $890 \mathrm{~m}$ a.s.l. The climatological station is a part of the experimental ecological study site of Bílý Kř́ž (Marková et al. 2009) which includes also a spruce stand.

During 1989-1999, an observer recorded the daily sum of precipitation at 07:00. A rain gauge placed in an open place $1 \mathrm{~m}$ above the ground was used for the measurements.

Precipitation measurements have been automatized since 2000. An automatic rain gauge placed in an open place $1 \mathrm{~m}$ above the ground has been used for the measurements since that time. Precipitation sums are measured at $30 \mathrm{~s} \mathrm{in}-$ tervals, and 10 min mean values of these records are automatically stored in the data-logger.

More detailed analysis of precipitation conditions was done for the 20-years period 19972016 and/or period 2000-2016 during which the measurements have been automatized. The mean annual sum of precipitation, mean and maximum daily sum of precipitation, precipitation intensity and frequency, and potential evapotranspiration were evaluated for this period.

\section{Definition of the terms:}

- precipitation intensity without rain: $0 \mathrm{~mm} \mathrm{~h}^{-1}$ light rain: $0.1-2.5 \mathrm{~mm} \mathrm{~h}^{-1}$ moderate rain: $2.6-10 \mathrm{~mm} \mathrm{~h}^{-1}$ heavy rain: $10.1-50 \mathrm{~mm} \mathrm{~h}^{-1}$ violent rain: $>50 \mathrm{~mm} \mathrm{~h}^{-1}$

- Lang's rain factor (humidity index) is defined according to Sobíšek (1993) for the warm period (April-September) as:

$$
f=P / A T
$$

where $\mathrm{P}$ - annual sum of precipitation ( $\mathrm{mm})$, $\mathrm{AT}$ - mean annual air temperature $\left({ }^{\circ} \mathrm{C}\right)$.

- Standardized precipitation index is defined according to Tolasz et al. (2007)

$$
S P I=\left(P-P_{L T}\right) / S D_{L T}
$$

where $\mathrm{P}$ - monthly sum of precipitation (mm), $\mathrm{P}_{\mathrm{LT}}$ - long-term mean monthly sum of precipitation $(\mathrm{mm}), \mathrm{SD}$ - standard deviation of the long-term mean monthly sum of precipitation. Monthly sums of precipitations from the period of 1989-2016 were used for the calculation of the long-term values.

Obtained air temperature data were statistically evaluated (regression analysis, descriptive statistics).

\section{Results and Discussion}

The mean annual sum of precipitation was $1294 \pm 225$ mm at the study site of Bílý Krríž in the 1997-2016 (Fig. 1). The mean annual sum of precipitation is $1100 \pm 100 \mathrm{~mm}$ for the region where the study site is situated based on the extrapolation of data from nearby meteorological stations for the period 1961-2000 as presented by Tolasz et al. (2007). The mean annual sum of precipitation was higher in 1997-2016 about $190 \mathrm{~mm}$ compared to that reported by Tolasz et al. (2007). The mean annual precipitation was $3.5 \pm 0.6 \mathrm{~mm}$ and this value showed a statistically significant decreasing trend during 1997-2016 (Fig. 2A, 2B).

The mean daily maximum sum of precipitation was $57.8 \pm 23.6 \mathrm{~mm}$ at the study site in 19972016 (Fig. 1). The highest daily maximum sum of precipitation was observed in 2010 (105.8 mm).

Precipitation intensity was evaluated at the study site in the 2000-2016 when the measurements of precipitation were made automatically (Fig. 3). The frequency of events without rain was increasing during this time and the trend was determined to be statistically significant (correlation coefficient 0.66). Conversely, the frequency of light $\left(0.1-2.5 \mathrm{~mm} \mathrm{~h}^{-1}\right)$ and moderate $\left(2.6-10.0 \mathrm{~mm} \mathrm{~h}^{-1}\right)$ rain events was decreasing. Again, the trends were determined be statistically significant (correlation coefficient were -0.60 and -0.64 , resp.). No statistically significant trend was found out for the frequency of heavy (10.1-50 $\mathrm{mm} \mathrm{h}^{-1}$ ) rain events. Heavy rain was recorded mainly in the warm period 


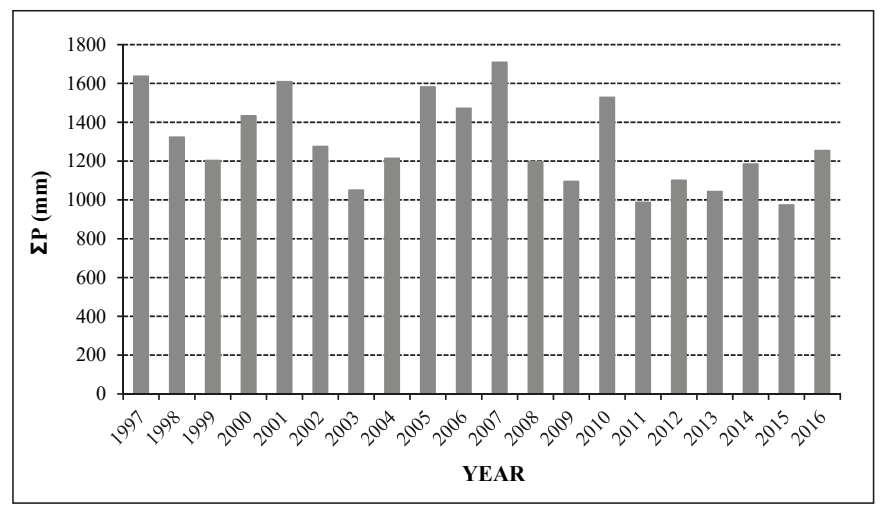

Fig. 1: Annual sum of precipitation at the study site of Bílý Kř́z (the Beskids Mts.) during 1997-2016.
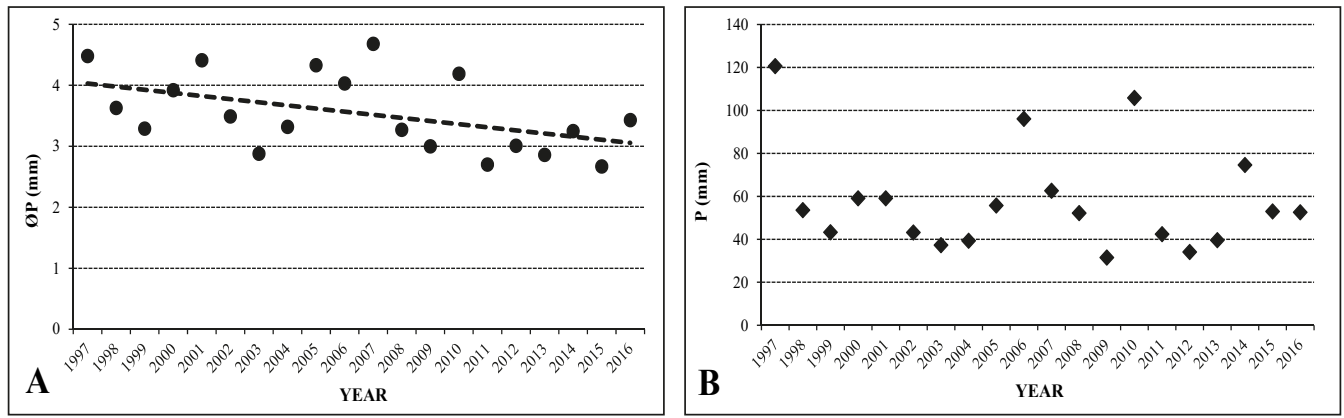

Fig. 2: Annual mean daily sum of precipitation and the trend of the annual mean daily sum of precipitation (A) and annual maximum daily sum of precipitation (B) at the study site of Bílý Kř́z (the Beskids Mts.) during 1997-2016.
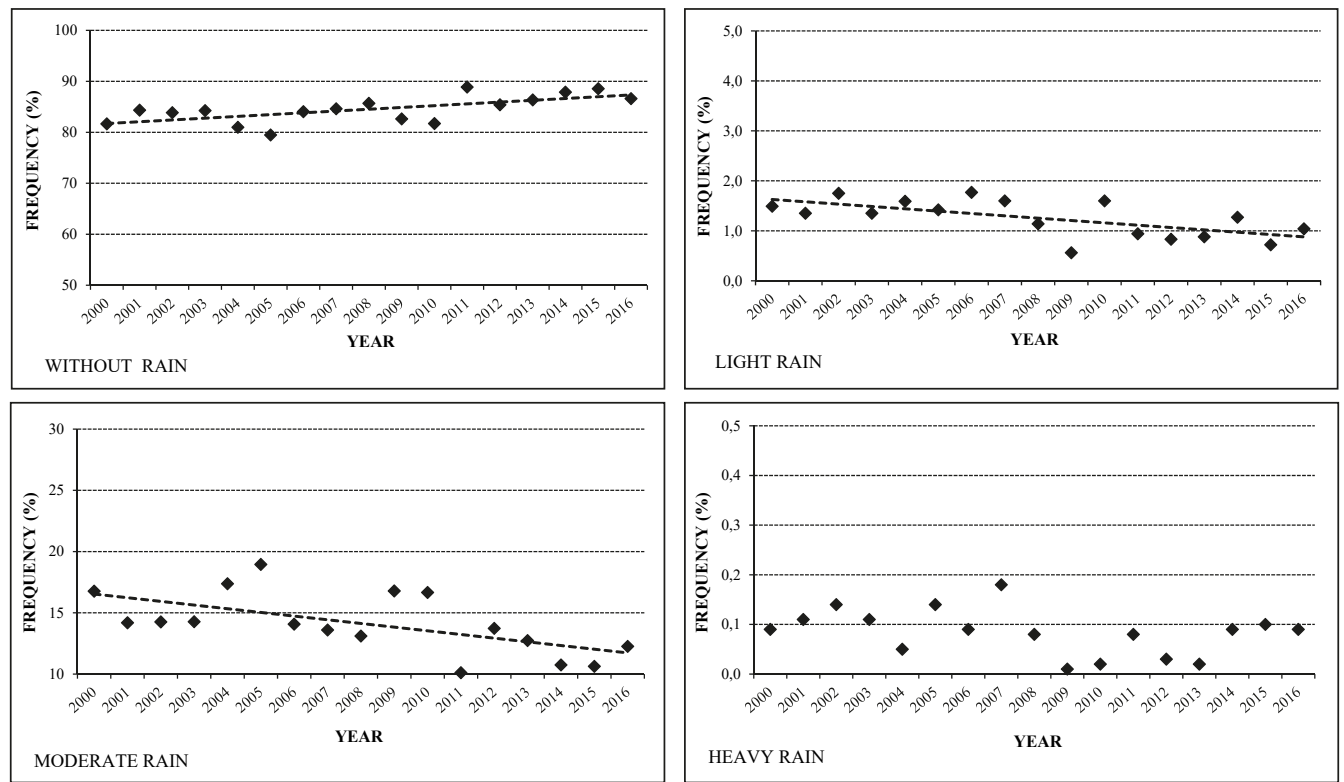

Fig.3: Frequency of events without rain and frequence of light $\left(0.1-2.5 \mathrm{~mm} \mathrm{~h}^{-1}\right)$, moderate $\left(2.6-10.0 \mathrm{~mm} \mathrm{~h}^{-1}\right)$ and heavy (2.6-10.0 $\mathrm{mm} \mathrm{h}^{-1}$ ) events rain at the study site of Bíly Kř́ź (the Beskids Mts.) during 1997-2016 (lines show the trend in the period of 2000-2016). 


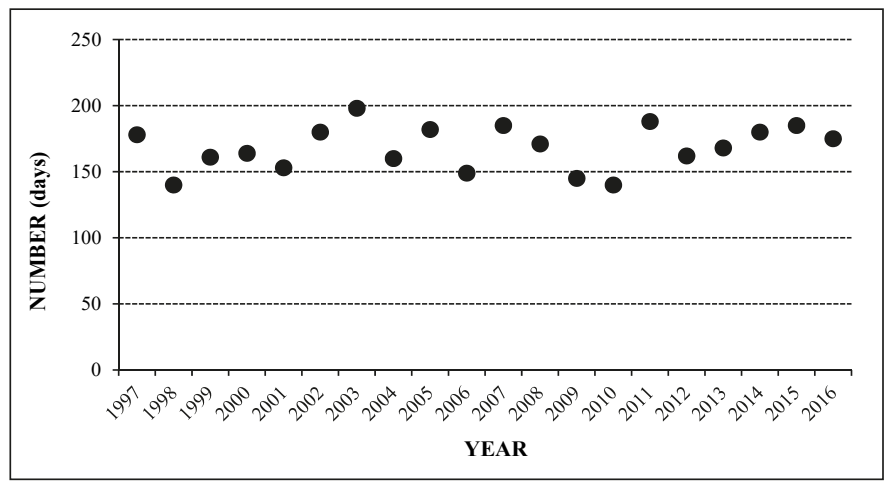

Fig. 4: Number of days without precipitation at the study site of Bíly Kriz (the Beskids Mts.) during 1997-2016.

of the years (April-September) (Romero et al. 1998, Szolgay et al. 2009). No violent rain events (> $50 \mathrm{~mm} \mathrm{~h}^{-1}$ ) was determined at the study site during 2000-2016.

The mean number of days without precipitation was $168 \pm 16$ during 1997-2016 (Fig. 4). No statistically significant trend in the number of days without precipitation was determined during the past 20 years (Quirmbach et al. 2012).

The number of days with daily sum of precipitation in the range $0.1-9.9 \mathrm{~mm}$ was decreasing during 1997-2016 (Fig. 5 A-C), but no statistically significant trend was determined (significance level $\alpha=0.05$, correlation coefficient $-0.47,-0.59$ and -0.64 , resp.). The number of rainy days was so decreasing (Ventura et al. 2002), but no statistically significant trend was determined for the number of days with daily sum of precipitation $\geq 10 \mathrm{~mm}$ (Fig. 5D).

The humidity indexes could be used to describe water conditions at the site. Lang's rain factor and standardized precipitation index are ones of these indexes.

Values of Lang's rain factor (f) calculated for the warm period (April-September) was decreasing at the study site during 1997-2016
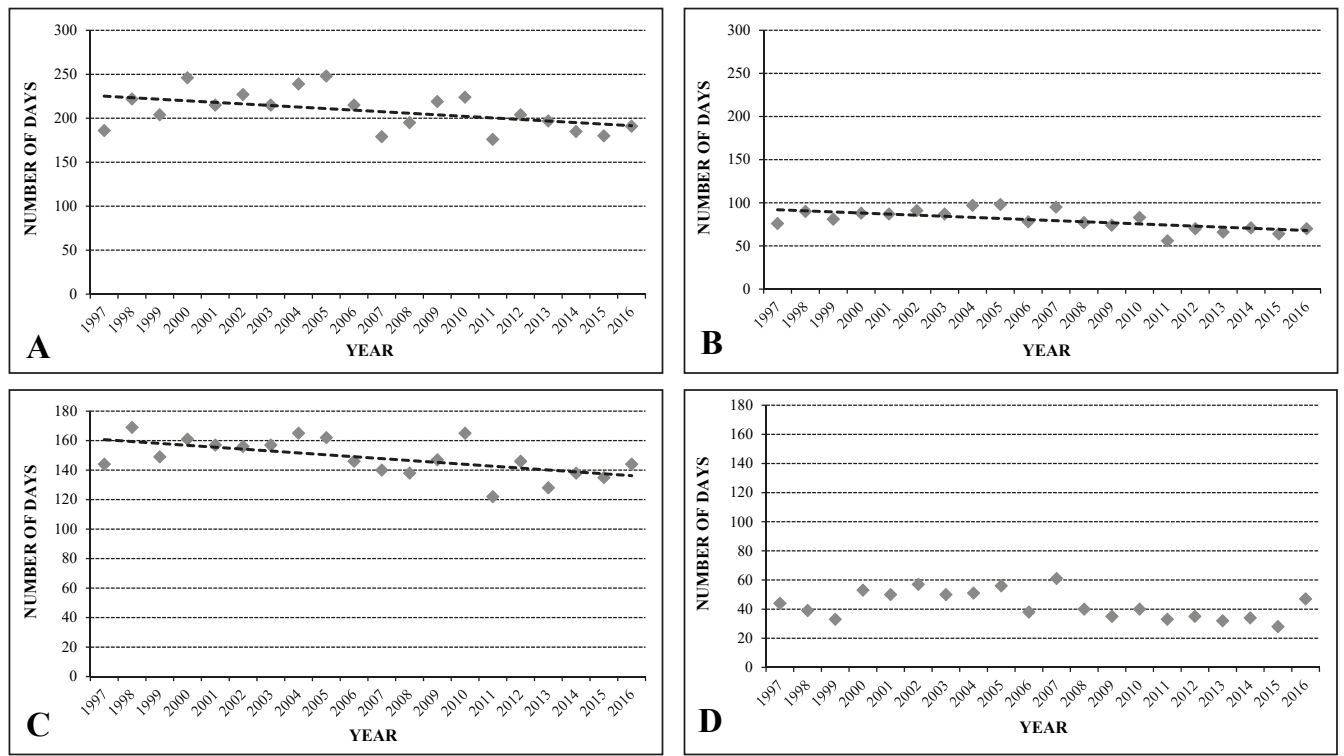

Fig. 5: Number of days with different daily sums of precipitation at the study site of Bily Kríz (the Beskids Mts.) during 1997-2016 (lines show the trend during 1997-2016).

A-daily sums of precipitation $\geq 0.1 \mathrm{~mm}, \mathrm{~B}$-daily sums of precipitation $\geq 1.0 \mathrm{~mm}, \mathrm{C}$-daily sums of precipitation $\geq 5.0 \mathrm{~mm}$, $D$-daily sums of precipitation $\geq 10.0 \mathrm{~mm}$. 
(Fig. 6). Its trend was found to be statistically significant (correlation coefficient -0.60). The mean value of Lang's rain factor was $78 \pm 27$ for the period 1997-2016. Sites are classified as humid when $\mathrm{f}=60-100$ and as perhumid when f > 100 (http://www.cbks.cz/sbornikRackova03/ sections/5/Dufkova-3.pdf). The study site has changed from being a perhumid to humid area during the studied 1997-2016 period.

A negative value of the standardized precipitation index (SPI) indicates drought at the site. SPI is usually reported as the number of consecutive months when the SPI is < $<-1$. SPI values were between 0 - 5 at the study site during 19972016 (Fig. 7). The mean SPI values was 2. A statistically significant increasing trend in SPI values was determined for the past decade (correlation coefficient 0.52) (Verdni and Todisco 2011).

\section{Conclusions}

It is evident that some parameters of precipitation conditions have differed in comparison to long-term values at the mountain study site of Bílý Kř́iž (the Beskids Mts., Czech Republic). Tables 1 and 2 present comparisons of selected long-term precipitation characteristics with precipitation characteristics for the period 1997-2016. The results show a slightly increasing annual sum of precipitation and slightly increasing number of days without precipitation. No statistically significant trend was found for the number of days with heavy rain. The study site changed from being a perhumid to humid type of site in accordance with Lang'rain factor. More dry periods were determined at the past decade according to standardized precipitation index.

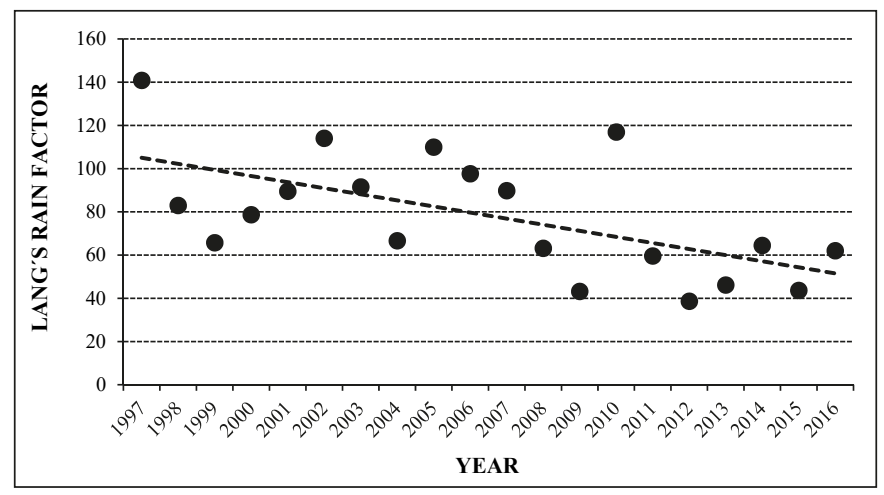

Fig. 6: Lang's rain factor determined for the warm period (April-September) at the study site of Bíly Króz (the Beskids Mts.) during 1997-2016 (line shows the trend during 1997-2016).

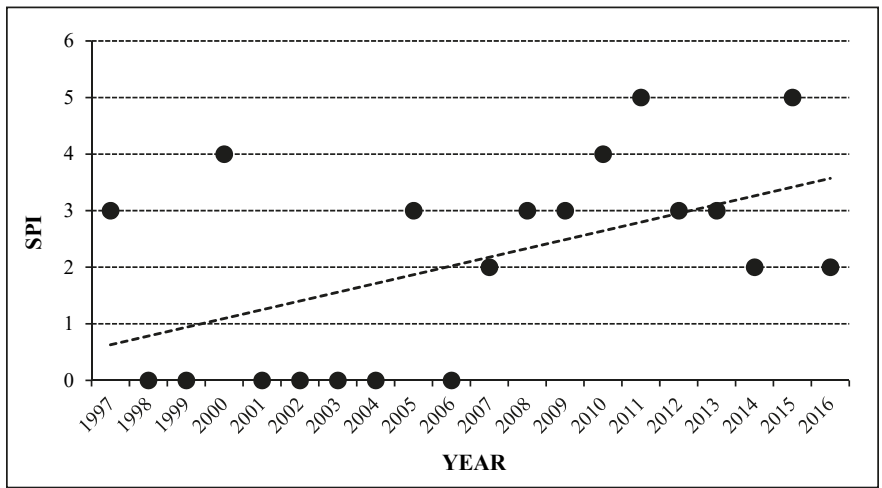

Fig. 7: Standardized precipitation index at the study site of Bílý Kř́ž (the Beskids Mts.) during 1997-2016 (line shows the trend during 1997-2016). 
Tab. 1: Comparison of mean annual sum of precipitation at the study site of Bíly Kŕžz (the Beskids Mts.) with the long-term values determined for the region.

\begin{tabular}{l|c}
\hline & $\begin{array}{c}\text { Mean annual } \\
\text { sum of precipitation (mm) }\end{array}$ \\
\hline $\begin{array}{l}\text { Long-term mean } \\
\text { at the study site of Bílý Kříž } \\
\text { during 1997-2016 }\end{array}$ & $1294 \pm 225$ \\
$\begin{array}{l}\text { Long-term mean in the region } \\
\text { during 1961-2000* }\end{array}$ & $1000-1200$ \\
$\begin{array}{l}\text { Normal value in the region } \\
\text { during 1961-1990 ** }\end{array}$ & $1000-1200$ \\
$\begin{array}{l}\text { Normal value in the region } \\
\text { during 1981-2010*** }\end{array}$ & $1000-1200$ \\
\hline
\end{tabular}

* according to Tolasz et al. 2007

** according the http://portal.chmi.cz/historicka-data/pocasi/mapy-charakteristik-klimatu

*** according the http://portal.chmi.cz/historicka-data/pocasi/mapy-charakteristik-klimatu

Tab. 2: Comparison of other chosen precipitation parameters at the study site of Bíly Kríz (the Beskids Mts.) with the long-term values determined for the region.

\begin{tabular}{|c|c|c|}
\hline & 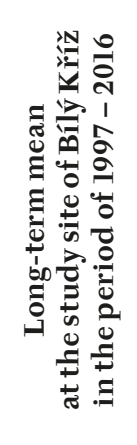 & 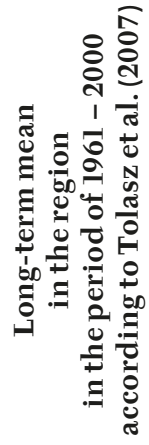 \\
\hline Mean annual maximum of precipitation (mm) & $58 \pm 24$ & $50-60$ \\
\hline Lang's rain factor for the warm period (April-September) & $78 \pm 24$ & $>100$ \\
\hline Standardized precipitation index & 2 & 2 \\
\hline Number of days with daily sum of precipitation $\geq 0.1 \mathrm{~mm}$ & $208 \pm 22$ & $170-190$ \\
\hline Number of days with daily sum of precipitation $\geq 1.0 \mathrm{~mm}$ & $148 \pm 16$ & $140-150$ \\
\hline Number of days with daily sum of precipitation $\geq 5.0 \mathrm{~mm}$ & $80 \pm 11$ & $>70$ \\
\hline Number of days with daily sum of precipitation $\geq 10.0 \mathrm{~mm}$ & $43 \pm 9$ & $>32$ \\
\hline
\end{tabular}




\section{Aknowledgement}

This work was supported by the Ministry of Education, Youth and Sports of CR within the programme INTER-EXCELENCE (INTERCOST), grant No. LTC17007 and by the Ministry of Education, Youth and Sports of CR within the National Sustainability Program I (NPU I), grant number LO1415.

\section{References}

Begueria, S., Vincente-Serrano, S.M. 2006: Mapping the hazard of extreme rainfall by peaks over threshold extreme value analysis and spatial regression techniques. Journal of Applied Meteorology and Climatology, 45: 108-124.

Casas, C.M., Herrero, M., Ninyerola, M., Pons, X., Rodriguez, R., Riusb, A.,Redanoe, A. 2007. Analysis and objective mapping of extreme daily rainfall in Catalonia. International Journal of Climatology, 27: 399-409.

Cooley, D., NychKa, D. and Naveau, P. 2007. Bayesian spatial modeling of extreme precipitation return levels. J. Am. Stat. Assoc., 102: 824-840.

D'Asaro, F., D'Agostino, L., Bagarello, V. 2007. Assessing changes in rainfall erosivity

in Sicily during the twentieth century. Hydrol. Proc., 21: 2862-2871.

Fienera, P., Neuhausa, P., Botschekc, J. 2013: Long-term trends in rainfall erosivity - analysis of high resolution precipitation time series (1937-2007) from Western Germany. Agriculture and Forest Meteorology, 171-172: 115-123.

Ford, T.W., LABosier, Ch.F. 2017: Meteorological conditions associated with the onset of flash drought in the Eastern United States. Agricultural and Forest Meteorology, 247: 414-423.

HAERTER, J.O., Berg, P., Hagemann, S. 2010: Heavy rain intensitydistributions on varying time scales and at different temperatures. J. Geophys. Res., 115, D17102, doi: 10.1029/2009JD013384.

Henttonen, H.M., Mäkinen, H., Heiskanen, J., Peltoniemi, M., Laurén, A., Hordo, M. 2014: Response of radial variation of Scots pine to temperature, precipitation and soil water content along a latitudinal gradient across Finland and Estonia. Agricultural and Forest Meteorology, 198-199: 294-308.

Ivanov, L.A., 1928. Zur methodik der transpirationbestimmung am standard. Ber. Dt. Bot. Ges. 46: 306-310.
Jódar, J., Custodio, E., Liotta, M., Lambán, L.J., Herrera, C., Martos-Rosillo, S., Sapriza, G., Rigo, T. 2016: Correlation of the seasonal isotopic amplitude of precipitation with annual evaporation and altitude in alpine regions. Science of the Total Environment, 550: 27-37.

Jongena, M., PereiraA, J.S., Igreja Airesb, L.M., Pioc, C.A. 2011: The effects of drought and timing of precipitation on the inter-annual variation in ecosystem-atmosphere exchange in a Mediterranean grassland. Agricultural and Forest Meteorology, 151: 595-606.

Marková, I., PaVelKa, M., TomášKová, I., Janouš, D. 2009: Yearbook of Meteorological Measurements 2007. Experimental ecological study site Bílý Kříž (Moravian-Silesian Beskids Mts.). Ústav systémové biologie a ekologie AV ČR, v. v. i., Brno, $81 \mathrm{pp}$.

Meusburger, K., Steel, A., Panagos, P., Montanarella, L., Alewell, C. 2012. Spatial and temporal variability of rainfall erosivity factor for Switzerland. Hydrol. Earth Syst. Sci., 16: 167-177.

Michaelides S.C., Tymvios, F.S., Michaelidou, T. 2009: Spatial and temporal characteristics of the annual rainfall frequency distribution in Cyprus. Atmospheric Research, 94: 606-615.

Peng, S., Piao, S., Shen, Z., Ciais, P., Sun, Z., Chen, S., Bacour, C., Peylin, P., Chen, A. 2013: Precipitation amount, seasonality and frequency regulated carbon cycling of a semi-arid grassland ecosystem in Inner Mongolia, China: A modelling analysis. Agricultural and Forest Meteorology, 178-179: 46-55.

Pessacg, N., Flaherty, S., Brandizi, L., Solman, S., PAscual, M. 2015: Getting water right: A case study in water yield modelling based on precipitation data. Science of The Total Environment, 537: 225-234.

Poulter, B., Pederson, N., Liu, H., Zhu, Z., D'Arrigo, R., Ciais, P., Davi, N., Frank, D., Leland, C., Myneni, R., Piao, S., Wang, T. 2013: Recent trends in Inner Asian forest dynamics to temperature and precipitation indicate high sensitivity to climate change. Agricultural and Forest Meteorology, 178-179: 31-45.

Quirmbach, M., Einfalt, T., Langstädtler, G. 2012: Climate change analysis of precipitation data for North Rhine-Westphalia. Atmospheric Research, 109-110: 1-13.

Allen, M.G., Ingram, W.J. 2002: Contraints on future changes in climate and the hydrologic cycle. Nature, 419: 224-232. 
Romero, R., Guijarro, J.A., Ramis, C., Alonso, S. 1998. A 30-year (1964-1993) daily rainfall data base for the Spanish Mediterranean regions: First exploratory study. International Journal of Climatology, 18: 541-560.

Rotunno, R., Houze, R.A. 2007. Lessons on orographic precipitation from the Mesoscale Alpine Programme. Q. J. R. Meteorol. Soc., 133: 811-830.

Sobíšeк, B. et el. 1993: Meteorological Dictionary, Interpretive and Terminological (in Czech). Academia: Praha, 54 pp.

Szolgay, J., Parajka, J., Kohnová, S., Hlavčová, K. 2009: Comparison of mapping approaches of design annual maximum precipitation, Atmospheric Research, 92: 289-307.

Tolasz, R., BRÁzdIL, R., Bulír̆, O. et al. 2007: Climate Atlas of the Czechia. Český hydrometeorologický ústav, Univerzita Palackého, Praha, $256 \mathrm{pp}$.

Vergni, L., Todisco, F. 2011: Spatio-temporal variability of precipitation, temperature and agricultural drought indices in Central Italy. Agricultural and Forest Meteorology, 151:301-313.

Trapero, L., Bech, J., Lorente, J. 2013: Numerical modelling of heavy precipitation events over Eastern Pyrenees: Analysis of orographic effects. Atmospheric Research, 123:368-383.

Ventura, F., Rossi Pisa, P., Ardizzoni, E. 2002: Temperature and precipitation trends in Bologna (Italy) from 1952 to 1999. Atmospheric Research, 61: 203-214.

Vergni, L., Todisco, F. 2011: Spatio-tempotal variability of precipitation, temperature and agricultural drought indices in Central Italy. Agricultural and Forest Meteorology, 151:301-313.

WaI, K.M., Wang, X.M., Lin, T.H., Wong, M.S., Zeng, S.K., HE, N., NG, E., LAU, K., Wang, D.H. 2017: Observation evidence of a long-term increase in precipitation due to urbanization effects and its implications for sustainable urban living. Science of The Total Environment, 599-600: 647-654.

Wilson, P.S., Toumi, R. 2005: A fundamental probability distribution of heavy rainfall. J. Geophys. Res., Lett. 32, L14812, doi: 10.1029/2005GL022465.

Wotling, G., Bouvier, C., Danloux, J., Fritsch, J.-M. 2000. Regionalization of extreme precipitation distribution using the principal components of the topographic environment. Journal of Hydrology, 233: 86-101. 